\title{
Detection of Potentially Creative Students for Informatics Activities
}

\author{
http://dx.doi.org/10.3991/ijep.v6i1.5156 \\ Walfredo González Hernández \\ Universidad de Matanzas, Matanzas, Cuba
}

\begin{abstract}
Creativity development is one of the most important human features. It must be developed at universities. The creative development in informatics engineers for computerization processes is very important for many countries. Forming an engineer with these qualities is important and their detection is of utmost importance.
\end{abstract}

Index Terms-Creativity, creativity development, detection of creativity potentiality.

\section{INTRODUCTION}

The development of human societies has been visibly permeated by the impact of technology and society more than ever. A technology that sets new standards in the development of human endeavor is informatics. Informatics form the basis of information society and is a base for management knowledge. The increased storage capacity and the speed of information processing, in conjunction with the decrease in the size of the equipment, led to the treatment of large volumes of information needed in various branches of knowledge. Thus, informatics networks have increased levels of communication based on an increase in transmission speed accompanied by significant increases in the reliability of information.

If not raised before, it can be inferred that at present information technology and communications play an important role in the development of a country. For this purpose, the universities give special attention to the training of highly qualified personnel needed for the preparation of development strategies in this regard. One of the characteristics necessary in this type of personnel is the development of creativity due to variably growing conditions and the speed of change of their professional environment. In this sense, the diagnosis of a creative potential is the subject of strong controversy in the scientific community and in particular, the diagnosis of the creative potential in informatics science has not found enough scientific treatment.

\section{DEVELOPMENT}

Today's society has as one of its key feature production and consumption of information supported by information technology and communications. Production systems are capable of processing and producing information of vital importance to any country which leads to the formation of human capital in this activity with a high degree of creativity. Research in this area has been sporadic [4, 20, 47], but the psychological analysis of creativity is essential in a scientific work devoted to the topic.

Different psychological theories since the emergence of psychology as a science in the mid-nineteenth century have studied the subject of creativity. Current important psychological schools in the study of creativity are cognitivism, humanism and cultural historical approach.

From the analysis of the authors' cognitivist criteria, the author can systematize different elements that are important psychological inadequacies of these ideas:

1. It develops only the cognitive side leaving relegated to the background the affective process analysis.

2. We analyze the human development as a process of accommodation to external conditions.

3. Limiting the study of social relations in the development of creativity.

However [3, 9, 20, 33, 46] interpret the system focusing on the construction and development of ideas as a hierarchy of discrimination and overlap, differentiation, integration and interaction between the environment and the internal complexity. In terms of practical application, the complexity theory can be used in communications research, counseling information and creativity. The cognitive complexity of individuality is more effective depending on the communication and use of information. On the other hand, the French sociologist Edgar Morin [34] argues that complex thinking is moving in the constant tension of aspiring to know not parceled, yet non-reductionist information, and recognizes the incompleteness of all knowledge. That is why the author recognizes the complexity of the creative process.

The humanist psychologists agree that creativity is a property of all human potential, associated with the concept of mental health, and give a leading role to the determination of personality and their ability to set goals to unfold its full potential.

An analysis of Cuban authors [15, 16, 17, 20, 29, 31, 32], representatives of the cultural historical approach, consider that a first condition in the study of creativity is to analyze the historical and cultural approach in which the individual is, its historical development and the interactions that occur between the individual and society in its evolution as a personality. This last item is very important for the analysis of creativity in the informatics context.

The creative process present in people who are dedicated to solve informatics problems for organizations or during class has different characteristics to other sciences, because it is permeated by the characteristics of the branch of human knowledge in which it develops.

This is the opinion of the author who worked with different informatics systems and also created one of the concepts that express the creativity of informatics, especially when these systems lead to a paradigm shift. The author believes that the novel in terms of computing terms 
can be found in a complex process in which results are obtained as concepts, procedures, models, systems and / or informatics algorithms that have not been performed previously in a social context.

An outstanding element points to the social and historical context in which the individual develops $[15,16,19$, $20,21,32,33]$, as in the definition discussed above, since it addresses the problem of the student creator of algorithms already discovered or not, and a software producer in business needs the developer who is in softwareproducing companies. In the analysis of creativity in the context of computing it is essential to consider the conditions under which it develops and the resources available to each one of them that determine the platform used to develop the systems. Thus the consideration of social demands is an important element to consider in the development of creativity in the context of informatics education.

Although it must express the integrity of the cognitive and affective, the attachment process in the case of information is very important. The motivation for carrying out activities on solving informatics problems and contradictions they contain, promotes and leads the implementation of actions needed to remedy cognitive action [17, 18, 19, 48]. Cognitive activity in computing is preceded by intense activity derived from motivational contradictions expressed in the problematic situations that drive the individual to the creation in the informatics. The characteristics listed [16, 20, 26, 32, 33] are adapted in order to study what needs to redefine its indicators in the informatics context that the author's consideration include:

Generation: This refers to the original production itself, autonomously, which is related to invention and discovery to act independently, to reach the creative transformation. Indicators are:

The production of different concepts, models, algorithms and codes to solve a problem. A determination of the algorithms and concepts is applied in solving a problem.

Extension: This refers to the production of ideas, questions, problematizing, and solutions that advance the knowledge and experience of themselves and / or others. It is the opinion of the author, that it refers to obtaining Informatics algorithms which are not studied in classes, programs and models which integrate complex data types studied forming new types of data or problems to solve.

Indicators are:

Design and development of new systems, concepts, algorithms or codes that solve a problem.

Ideas to improve the systems, concepts, algorithms and codes in order to solve an existing problem.

New arising problems from practice that can be computerized.

Flexibility is the ability to provide varied answers, changing ideas and overcome stiffness. The author expressed this in different data models, algorithms and codes used to represent the problem and determine its solution and its codification. The indicators are:

Find solutions to the problem.

Determine possible solutions to the problem from the informatics resources they have available.

Be aware and change their opinions based on existing criteria contrary to solve the problem if necessary.
Collaboration with the people involved in the process of building the software.

Autonomy: to think for ourselves, make decisions without belittling other people's judgments. Determine which of the algorithms obtained is the most efficient and which model best represents the relationships contained in the problem.

Using their own criteria in determining the algorithms and concepts to be applied in solving a problem.

Using the experience in the development of algorithms, codes or informatics systems.

It is the opinion of the author that a definition of creativity must take into account these elements, making it possible to define creativity as a complex computing in which results are obtained as concepts, procedures, models, systems and / or informatics algorithms related to the development aspects of information technology to meet social demands characterized by generation, expansion, flexibility and autonomy.

In the diagnosis of creative potential, informatics activity is considered necessary to characterize how this author understands it. Creative expression of informatics is part of the project as a fundamental form of the activity of this science. Several authors [2, 10, 13, 18, 19, 20, 25, 39, 47], among other definitions, have been asked about the informatics project. However, it is this author's opinion that the definitions mentioned in the literature do not represent the generality of the situations that can be found in the solution of problems related to informatics science. That is why the author considers the following definition:

There must be an action plan as a matter of a system which integrates the actions of its developers who contribute to the solution of a problem in a particular area of human knowledge in which it interferes with the use of at least one informatics system, which gives the right solution to enable and generate a product.

The author considers necessary to explain the key features of the definition proposed here:

A plan of action: the planning of activities to be performed in a series of actions, plays an important role in its further development. The development and implementation of this plan of action is contemplated in the methodologies for the elaboration of projects.

Where actions are integrated by their developers: This means that developers must implement a set of actions to solve your project and that these actions are inclusive, in which the solutions are not isolated or outside the context of their work project in the solution. It is also necessary for the solution that developers communicate closely with users. This points to the social aspect of the acquisition of knowledge to its solution as the concatenation of the solutions for each depending on their functions.

One problem with a particular area of human knowledge is: The penetration of informatics in the branches of human knowledge has raised the challenges in the production process with quality and competitive computerization.

With the use of at least one informatics system: In this aspect of the definition is addressed the informatics use to carry it out. The optimization of computing resources in the solution is very important to satisfy customer needs in relation to their equipment. 
Generate a product: the introduction of information production processes involves, ultimately, increased quality of life of society. In this sense, the developers have an ethical role to play because of the further implementation of the results.

That is why the diagnosis of students' creative potential should be based on the potential for work on a project basis for the solution of problems related to informatics science. One issue to consider, in the opinion of this author, is the essence of the formation of a informatics engineer. In engineering the fundamental problem is the solution of problems of informatization of production and service fields. In these processes needs to be included in a planning stage the main requirements and needs of the organization which are then executed.

Students must be prepared for the whole process of solving the problem by emphasizing the planning and direction of the same integrated already in the implementation phase. The design is an essential step in the development process. It helps to understand the details of the system, the interrelationships between the parts and subsystems and to go straight to implementation.

In the process described above are inserted methodologies for software development which stand between the OR and the so-called agile methodologies like XP, Scrum, among others. Each includes the planning and development of software, but with different characteristics because of their theoretical assumptions.

According to this author agile methodologies present an alternative to plan-oriented methodologies in increasingly more flexible and rapid changes for projects of medium and small-scale. In the case of projects developed by students will be used these methodologies especially XP, because of the organizations which intend to develop new products [47]. . For these methodologies in IT projects may be submitted only two roles: the programmer and the leader, which is a reference to explain the author's opinions regarding the diagnosis of students' creative potential.

Assume the roles discussed above involve students in the development of qualities important in influencing individual behavior. The responsibility that we assume a project, the organization of actions to perform as well as to express a high degree of development of the dimensions that involve future projections are closely related to motivation and the system of motives that regulate their actions; indicators of creativity [4, 19, 21, 26, 38]. For the solution of the project the creative personality requires indicators from which one can mention the questioning, reflection, custom framing, the proper valuation and intellectual daring, all this the author believes, should be diagnosed.

The diagnosis of informatics-related needs is vitally important because satisfaction is an element that allows to take these qualities into their computing performance. In this way students who do not possess qualities such as those expressed above for the achievement of sustainable informatics activities right from their involvement are not suitable. All points raised before, ask for the incorporation of information technology as part of the volitional activities of the personality.

However, the diagnosis of the issues above is discussed in research circles devoted to creativity. This author thinks that the issues raised cannot be resolved only with the application of various tests, while not denying their im- portance and validity to obtain information about the individual. For this author it is convenient to develop a system of activities through which they reveal their field indicators related to affective computing that enables their effective diagnosis. Similarly, it is necessary to evaluate the reflection carried out in this system of activities, the decision making and its subsequent execution.

It should be noted that the solution of the problems contained in this set of activities should be assessed by the teacher as a process. This should take into account the development of the qualities of personality that is achieved with this system of activities, matters necessary to evaluate the potential that is counted and the levels of development that are likely to be achieved. To achieve the solution of increasingly complex problems integrating all their resources in terms of obtaining personological information, is crucial. This approach to the subsystems in the affective sphere should be supported with techniques known as the ten desires (I want to be) among others, which reflect the development that is reached.

For the creative process of cognitive processes, which reach their highest expression in thought, some factors are considered very important by several authors among which are $[1,3,5,12,14,37]$.

The development of thought is a point of agreement with the authors that investigate creativity. A student among creative potential for informatics must develop ways to work and algorithmic thinking, ways of thought and logical processes excelling in the case of informatics modeling. The development of models that reflect user needs, consistent with changes expressed in informatics terms, represents a potential for the design of projects. For this author, you also need to diagnose students' ability to search for other problems where the solution proposed and implemented informatics seems effective.

It is necessary to consider the thought which has an adequate balance of its functions in such a way that it has no tendency to run [29]. Informatics is often expressed to students by trying to ignore the analysis and design phases of the project which is now one of the most common mistakes in developing informatics systems.

The use of heuristic programs for the proposed informatics education $[18,19]$ as part of the preparation for problem solving allows for training in this respect and its diagnosis.

In the creative potentiality analysis is necessary to stop at the theoretical results about multiple intelligence obtained by the Project Zero at Harvard University. For this author, in the development of informatics creativity it is necessary to take account of potential students to assume the roles of programmers and leading agile methodologies.

The performance in these roles plays a major role in the development of logical intelligence - mathematical and interpersonal intelligence as suggested by this author [21]. It is hoped that interpersonal intelligence will deepen some issues not addressed by the author in the article cited above. Interaction with users is essential in developing an informatics project for information about its environment as well as the computerization process to be performed. This requires understanding of the ideas that are raised and of communication. To remove communication barriers that may occur in project informatics. 
In human cognition one of the key elements in research is intuition. For the author it is a product of free associations that are established in a non-conscious intellectual state of rest after an arduous task. On the other hand Dehaene [8] proposes two types of non-conscious processes, subliminal processing and preconscious processing. The authors $[12,27,36,39]$ raise the dependency between intuition and experience, to realize which ones the individual possesses. However, several points of contact exist in the literature $[1,6,12,23,27]$ as well as the need for experience in business, speed and the need to have clearly defined mental structures.

This author's conceptions allow an approach to this problem through informatics activity. The need for a vast experience in this field of activity is important for finding solutions, and to this system approach activities with the pursuit of problems in reality $[18,19,20]$ can contribute to that intuition may be subject to diagnosis. The results of free associations are expressed in terms of solutions to various projects that occur with the use of different techniques such as brainstorming, among others, allowing an approximation of the process. That is why the diagnosis may arise in terms of experience and free associations that can be expressed about knowledge.

The importance of non-conscious processes is complementary to submitting ideas to get the verification logic. The introduction of software engineering elements allows the student to see if the planning of the proposed solution is obtained and if the model can be viable or not. This allows to reach a conclusion about the idea obtained while evaluating the resources used by the student to reach the correct solution.

As noted above, the author considers that there is the need to confront students with a system of activities whose solution is also expressed in the form of projects. Conduct analysis of the different situations with users to develop the model, take it to ways of doing things and get a product needs to qualities of thought such as flexibility, autonomy and independence.

You can not complete the treatment of the subject without addressing the university and the role it plays in the learning process in creativity. One of the most important creative skills is to look for problems which must be prepared by professionals. In this teaching the use of integrated problem with the project approach allows the development of creativity in student computing as shown in [20].

For this author the project approach implies for the student to have experience in informatics, to direct the solution process of IT projects appropriate to their level [20] formulated guidelines to enforce and regulate their activity. It also enables students to develop their future prospects as an informatics expert, to establish future industrial relations which serve as the future of computing. All of which makes it possible to diagnose their creative potential in informatics science.

The future transformation of reality by the student from the process of computerization and the selection of necessary tools show the active nature of the regulatory function of personality matters necessary in the development of creativity. This process of transformation which must occur on the mental level play an important role in imagination, thus contributing to its development.

The projects will be submitted for consideration by the teacher who determines if they are in correspondence with the student and their programming skills. From the search begins the life cycle of software until it concludes with the set-up and maintenance. The problems of individual projects motivate students towards a solution and they get the knowledge of the course, which in turn generates problems for other situations in which students develop the cognitive activity necessary for creativity $[14,20,21,26$, 37, 38].

At each meeting, from the prior interaction between student - teacher - groups, the participants determine the problem situation for the remaining students. It is the teacher who decides to present the problem situation based on the meeting earlier in the group, concerning interaction and the development of student projects.

For the solution of a programming project it is necessary for students to master the techniques of software engineering that enable them to design the software and then schedule and in this process, the formation of an objectoriented design which allows a better model of reality programming.

This process should take into account the points raised by this author, and there are theoretical underpinnings such as the system approach [19], the conceptual core of informatics science education [18] and the project with minimum requirements [20].

The latter also takes into account the level of development that the student has to face for solving a software problem and the required system of knowledge to be applied in the project.

The author demonstrates that the integration of these livelihoods enables the development of creativity.

\section{CONCLUSIONS}

So far, research on the detection of potentially creative students in informatics science has not been systematized or sufficiently addressed in the literature. This article presents an approach on which this study is based relying on the characteristics of informatics creativity and the fundamental way in which informatics activity is expressed: the project. It also proposes the creation of a system of activities conducive to the diagnosis of personality qualities necessary for the resolution of informatics projects such projects must also take into account the logicalmathematical intelligence and interpersonal intelligence.

\section{REFERENCES}

[1] B. D. Blume, J. G. Covin, "Attributions to intuition in the venture founding process: Do entrepreneurs actually use intuition or just say that they do?" Journal of Business Venturing 26 (2011) 137151. http://dx.doi.org/10.1016/j.jbusvent.2009.04.002

[2] R. B. Cagle. Your Successful Project Management Career. Library of Congress Cataloging-in-Publication Data. New York. USA, 2005.

[3] S. Charlton and P. Bakan, "Creativity and physiognomic perception". Personality and Individual Differences, 11 (1990) 419420. http://dx.doi.org/10.1016/0191-8869(90)90225-G

[4] A. Craft, "Studying collaborative creativity: Implications for education". Thinking Skills and Creativity. 3 (2008) 241-245. http://dx.doi.org/10.1016/j.tsc.2008.09.006

[5] M. Csickszentmihalyi. (2000) "Potenciando la creatividad personal". Revista Psicología. Edición Especial. http://homepage.mac. com/penagoscorzo/creatividad_2000/creatividad2.html

[6] E. Dane, M. G. Pratt, "Exploring intuition and its role in managerial decision making". Academy of Management Review. 32 (2007) 1, 33-54. 
[7] E. De Bono, (1992). Serious Creativity. Publisher: Harper Business.

[8] S. Deheane, J. Changeux, L. Naccache, J. Sackur, C. Sergent, "Conscious, preconscious, and subliminal processing: a testable taxonomy." Trends in cognitive sciences, 105 (2006) $204-210$. http://dx.doi.org/10.1016/j.tics.2006.03.007

[9] M. J. Driver, S. Steuert, "Integrative Complexity: An Approach to Individuals and Groups as Information Processing Systems", Administrative Science Quarterly 14 (1969) 272-285 http://dx.doi.org/10.2307/2391105

[10] A. Echaluce, (2002) La elaboración de un proyecto informático. http://web.jet.es/inforpesca/pagina_n.htm . Consultado en: 20/12/2014

[11] C. Expósito, (2006). Elementos de Metodología de la Enseñanza de la Informática. Ciudad de la Habana: Pueblo y Educación.

[12] Fu, Qiufang, Z. Dienes, Fu, Xiaolan, "The distinction between intuition and guessing in the SRT task generation: A reply to Norman and Price." Consciousness and Cognition 19 (2010) 478480. http://dx.doi.org/10.1016/j.concog.2009.12.006

[13] A. Garcia Pain, (2002) "La elaboración de un proyecto informático." Revista TIMagazine. En: http://www.terra.es/nformatica/articulo/html/inf70.htm

[14] E. Glazer, "Rephrasing the madness and creativity debate: What is the nature of the creativity construct?" Personality and Individual Differences. 468 (2009) 755-764. http://dx.doi.org/10.1016/j.paid.2009.01.021

[15] F. González, (1995). Comunicación, personalidad y desarrollo. La Habana: Pueblo y Educación.

[16] A. González, (1995). "Prycrea: pensamiento reflexivo y creatividad". La Habana: Academia.

[17] W. González, "La formación de conceptos y definiciones informáticas." Revista Atenas, 12 (2005) 13-45

[18] W. González, V. Estrada, M. Martínez, "Propuesta metodológica para la formación del profesional informático desde la producción." Revista Atenas, 12 (2005) 64 - 72.

[19] W. González, V. Estrada, M. Martínez, (2006). "El enfoque de sistema en la enseñanza de la Informática para el desarrollo de la creatividad." Revista Enseñanza Universitaria. Facultad de Educación. Universidad de Sevilla. España.

[20] W. González, "Creativity Development in Informatics Teaching Using the Project Focus." International Journal of Engineering Pedagogy (iJEP), 3 (2013) 63-70. http://dx.doi.org/10.3991/ijep. v3i1.2342

[21] W. Gonález (2005). Implicaciones de la intelígencia lógica - matemática en el desarrollo de la creatividad informática. Recrearte.

En: http://www.iacat.com/Revista/recrearte/recrearte02/walred o01.htm

[22] C. L. Hale, "Cognitive complexity-simplicity as a determinant of communication effectiveness." Communication Monographs , 47 (1980) 304-311. http://dx.doi.org/10.1080/03637758009376039

[23] H. W. Hendrick, "The ergonomics of economics is the economics of ergonomics." Proceedings of the Human Factors and Ergonomics Society, 40 (1996) 1-10 http://dx.doi.org/10.1177/1541931 29604000101

[24] H. Plessner, C. Betsch, T. Betsch (2008), The Nature of Intuition and its Neglect in Research on Judgment and Decision Making. Intuition in judgment and decision making. Taylor \& Francis Group. New York.

[25] Jones, Capers (2010), Software Engineering Best Practices Lessons from Successful Projects in the Top Companies. The McGraw-Hill. USA

[26] P. Kampylis, E. Berki, P. Saariluoma "In-service and prospective teachers' conceptions of creativity." Thinking $\begin{array}{llll}\text { Skills and Creativity, } 41 & \text { (2009) 15-29 }\end{array}$ http://dx.doi.org/10.1016/j.tsc.2008.10.001

[27] F. C. Keil, K. L. Lockhart, E. Schlegel, "A Bump on a Bump? Emerging Intuitions Concerning the Relative Difficulty of the Sciences." Journal of Experimental Psychology: General. 139 (2010) 1, 1-15

[28] T. V. Kudriatsev, "Algunos aspectos psicológicos y didácticos de la enseñanza problémica”. Pedagogía Soviética, 810 (1967) 34-56.
[29] A. F. Labarrere, (1987) Bases psicopedagógicas de la enseñanza de la solución de problemas matemáticos en la escuela primaria. La Habana: Pueblo y Educación.

[30] M. I.,Majmutov, (1983) La enseñanza problémica. La Habana: Pueblo y Educación.

[31] M. Martínez, (1980). La enseñanza problémica de la filosofía marxista leninista. La Habana: Ciencias Sociales.

[32] M. Martínez, (1999). El desarrollo de la creatividad mediante la enseñanza problémica en la actualidad. Teoría y práctica. Curso 6 Pedagogía 1999. La Habana.

[33] M. Martínez, (1995). Calidad educacional, actividad pedagógica y creatividad. La Habana: Academia.

[34] E. Mori, B. Cyrulnik, (2005). Diálogos sobre la naturaleza humana. Editorial PAIDOS.

[35] A. Pantoja, (2003). Influencia del LOGO en la capacidad creativa del niño del Tercer Ciclo de Educación Primaria. Tesis en Opción al grado científico de Doctor en Pedagogía. Universidad de Jaén.

[36] D. O'Keefe, \& R. M. Brady, "Cognitive complexity and the effects of thought on attitude change." Social Behavior and Personality 8 (1980), 49-56. http://dx.doi.org/10.2224/sbp.1980.8.1.49

[37] M. Romo, (1997). Psicología de la creatividad. Barcelona: Paidós.

[38] I. Zorana, "Creativity Map: Toward the Next Generation of Theories of Creativity". Psychology of Aesthetics, Creativity and the Arts. 31 (2009) 17-21.

[39] B. Walters, Tang, Zaiyong. (2006). IT-Enabled Strategic Management: Increasing Returns for the Organization . Idea Group Publishing. Ney York. USA

[40] M. A. Bracho Arcos, (2003). Proyecto de un programa de gestión empresarial. En: http://www.uhu.es/17117/Proyecto\%20de \% 20un\%20programa\%20de\%20gestion\%20empresarial.ppt.

[41] O. D'Angelo, (2002). El Desarrollo Profesional creador (DPC) como dimensión del Proyecto de Vida en el ámbito profesional. En: http://www.clacso.edu.ar/ libros/cuba/angelo2.rtf. Consultado $15 / 04 / 2015$

[42] S. de la Torre, (2002). Creatividad en la reforma española. En http://educacion.jalisco.gob.mx/consulta/educar/10/10saturn.html. Consultada 12/02/2015

[43] D. De Prado, (2003). Creatividad para transformar sustancialmente las curriculares: una estrategia. En http://www.iacat.com/webcientifica/educrea\%20capitulo\%20V.pd f. Consultado 12/06/2015

[44] J. R. Dunn, (2000). Creativity: An Interview with Dr. E. Paul Torrance. Volume I, Number 11, (Interview 1, November, 2000). http://www.psychjournal.com/Interviews/November00 Torrance1. $\underline{\mathrm{htm}}$

[45] J. Lee, (2003) Cognitive Complexity and Methodical Training: Enhancing or Suppressing Creativity. Jungwoo Lee, Duane P. Truex. http://www.informatics.org/proceedings/hicss/0493/04937/ 04937007.pdf. Consultado en: 22/9/2015

[46] F. Menchén, (2010) Creatividad: el arte de reinventar la vida. Entrevista con el Dr. Francisco Menchén Bellón. Revista Digital Universitaria. UNAM. Disponible en: http://www.revista.unam. $\underline{\mathrm{mx} / \text { vol.10/num12/art91/int91.htm }}$

[47] D. Graziotin, (2013) "The Dynamics of Creativity in Software Development", 14th International Conference on Product-Focused Software Process Improvement (PROFES 2013) - Doctoral Symposium Proceedings, figshare. DOI:10.6084/m9.figshare.703568. Available: http://figshare.com/articles/The_Dynamics_of_Creati vity in Software Development/703568

\section{AUTHOR}

Walfredo González. Graduate degree in education specialty of mathematics and informatics. Master on Didactic mention Mathematics educations and PhD of Pedagogical Sciences. Coordinates the Laboratories of Technologies in Educations of University of Matanzas. Has published over 15 papers in refereed journals.

Submitted 20 October 2015. Published as rsubmitted by the author 23 January 2016. 